\author{
Eva Sicherl \\ Filozofska fakulteta, Ljubljana
}

\title{
Diminutive Nouns and Verbs in Slovene Compared to Their English Equivalents
}

Protistavna analiza samostalniških in glagolskih manjšalnic v slovenščini in angleščini jasno kaže, da sta tvorba in raba manjšalnic v slovenščini vezani na oblikoslovne značilnosti samostalnikov in glagolov ter posledično njihove morfološko-leksemske lastnosti, medtem ko ostaja težišče manjšalniške tvorbe in rabe $v$ angleščini vezano na skladnjo oziroma skladenjsko-pomensko rabo določenega leksema. V vseh jezikih je manjšalnost ena osnovnih pomenotvornih prvin, ki jo lahko izražamo predvsem morfološko, kot na primer v slovenščini, ali predvsem skladenjsko, kot na primer v angleščini. Kot pomenotvorna prvina samostalniška manjšalnost $\mathrm{v}$ slovenščini pomembno vpliva tudi na razvoj terminologije - v tem primeru se manjšalnica kot jezikovna metafora pomensko osamosvoji in postane strokovni termin; tega pojava angleščina praktično ne pozna.

A contrastive analysis of nominal and verbal diminutives in Slovene and English clearly shows that diminutive formation and use of diminutives in Slovene are tied to the morphological characteristics of nouns and verbs, and, consequently, their morphological-lexemic features, whereas the focus of diminutive formation and use in English remains bound to the syntactic use, or rather, the respective syntactic-semantic use of a given lexeme. In all languages, diminutiveness is a basic element of semantic extension, which can, however, be realized predominantly morphologically, as is the case in Slovene, or predominantly syntactically, as is the case in English. As an element of semantic extension, nominal and, more rarely, verbal diminutiveness in Slovene also plays a crucial role in the development of terminology - in this case the diminutive as language metaphor gains semantic independence and becomes a technical term, a phenomenon that is practically unknown in English.

\section{Introduction}

The present article deals with various ways diminutiveness can be expressed in Slovene and English respectively; the focus is on word-formational and syntactic properties of diminutive structures in the two languages concerned. While both languages can to some degree express diminutiveness, which is a language universal, ${ }^{1}$ in similar ways from the word-formational point of view, a more detailed analysis shows that because of language-typological differences between English (analytic language) and

${ }^{1}$ More on diminutiveness as language universal and on various ways different languages use to express diminutiveness can be found in Schneider (2003, 4, 7-10). 
Slovene (synthetic language), diminutiveness should be studied beyond mere lexical word formation, surpassing the boundaries of single words or syntactic phrases. In the present article the treatment of diminutiveness and the various ways in which it can be expressed is limited to nominal and verbal forms as the inclusion of other diminutive word classes would surpass the intended scope of the present article.

\section{Patterns for Expressing Diminutiveness in Slovene}

Since Slovene is a synthetic language, formation of diminutives by means of affixation is the most common way of expressing diminutiveness, similar to other Slavic languages. While diminutives in Slovene mainly belong to the word class of nouns, diminutiveness can also frequently be observed in verbs, adjectives and their adverbial derivatives, rarely also interjections and even numerals (see an overview in Černe 2010, 24, for Slovene, and Schneider 2003, 5, for some other European languages).

\subsection{Nominal Diminutives}

Slovene produces nominal diminutives by attaching one of numerous suffixes to a masculine, feminine, or neuter base. The exact number of affixes used for diminutiveness varies according to the linguistic sources consulted. Toporišič $(2004,143-44)$, for example, enumerates seventeen diminutive suffixes for masculine, feminine, and neuter diminutive nouns (-(an)ec, $-i \check{c}$, - (č $) e k,-e,-i,-k o,-\check{c} e$ for masculine diminutives; -ca, -(ič)ica, $-(i c ̌) k a,-i$ for feminine diminutives; $-e,-(e) c e,-(i) c ̌ e,-(e) c a,-k o,-i c a$ for neuter diminutives), while Bajec $(1950,127)$ lists eleven for all three genders. However, some of the suffixes mentioned either by Bajec or Toporišič are dated, dialectal, or extremely rare (e.g., -če for masculine; -iče, -če, -ko, -ica for neuter diminutives). A study by Vidovič Muha $(1995,160)$ itemizes nineteen diminutive suffixes: six for masculine diminutives $(-(e) k,-\check{c}(e) k,-(e) c,-i c ̌,-i c,-e t)$, six for feminine diminutives (-ica, -ka, -ca, -ice, -ce, -ke), and seven for neuter diminutives (-ce, -ece, $-k o,-i c ̌ e,-e c a,-c a,-k a)$. It needs to be stressed that these suffixes may also encode non-diminutive functions, so that the mere presence of one of the above suffixes in a lexeme does not automatically imply diminutiveness (e.g., while - $k a$ adds diminutive meaning in ptica $>$ ptička, its meaning is non-diminutive in noun derivatives like lovka or tipka; while -ek is diminutive in fantek or gumbek, it is simply used as a gender-marking suffix in maček or as an ordinary suffix to derive nouns from verbal bases in izdelek or pridelek). With the exception of feminine diminutives ending in $-i$ (e.g. mami, babi), diminutive nominal formations, regardless of the original declension-type of their base, enter the first nominal declension pattern of their respective gender.. The formation of nominal diminutives by means of suffixation in Slovene therefore follows the following pattern (see also Vidovič Muha 1995, 158-59):

$$
\begin{array}{ll}
\text { grič-ek } \leftarrow \text { [majhen] grič [-ø], [] } \rightarrow-e k, \text { grič- } & \text { (hillDIM) } \\
\text { jezer-ce } \leftarrow[\text { majhno] jezer[-o], [] } \rightarrow-c e, \text { jezer- } & \text { (lakeDIM) }
\end{array}
$$


Far less often clipping, reduplication, and compounding are used to produce synthetic diminutive nouns in Slovene (see Stramljič Breznik 2010). Thus, for example, clipping is used in the production of diminutive pet forms from personal names; similarly, reduplication can occasionally be found in names in children's literature or facetious (nick-)name forms.

\section{Ladislav $>$ Lado $>$ Ladko/Ladi \\ Žogica Marogica \\ Tonček Balonček}
(clipping, often further combined with affixation) (reduplication combined with suffixation) (reduplication combined with suffixation)

Compounding is encountered in nouns beginning with mikro- or mini- (e.g., minikrilo, minigolf, mikroprocesor, mikrofilm). While Slovene grammarians strictly consider the two elements mikro- and mini- as compound elements (see, for example, Stramljič Breznik 2007), English grammarians tend to treat them as prefixes rather than elements of a compound (see, for example, Bauer 2002, 1678). It is also worth noting that most of these formations in Slovene have been imported from foreign languages (usually English, often via German) as anglicisms or have been partly calqued (e.g., miniskirt > minikrilo).

Another form for expressing diminutiveness connected with nouns in Slovene is the analytic type. These formations normally contain nouns preceded by the adjectives meaning 'small' or 'little' usually majhen, droben, etc.), as in the following examples:
majhen kos
majhna hiša
[a small/little piece]
drobna deklica
[a small/little house]
[a small girl]

Interestingly, analytic diminutives and synthetic ones are nearly always interchangeable in Slovene; thus, for example, majhen kos torte [a small piece of cake] can be replaced by košček torte [pieceDIM of cake] without any change in meaning.

Another interesting feature of Slovene is the fact that the language quite often produces multiple layers of diminutives. In these structures, analytic and synthetic diminutives are often combined, and the resulting diminutives are emotionally colored (see Vidovič Muha 1995, 161).

$$
\begin{aligned}
& \text { fant }>\text { fantič }>\text { fantiček } \\
& \text { hiša }>\text { hiška }>\text { hiškica } \\
& \text { majhno jezerce } \\
& \text { majcena punčka } \\
& \text { hči }>\text { hčerka } \boldsymbol{a}^{2}>\text { hčerkica }
\end{aligned}
$$

$$
\begin{aligned}
& \text { [boy }>\text { boyDIM }>\text { boyDIMDIM] } \\
& \text { [house }>\text { houseDIM }>\text { houseDIMDIM] } \\
& {[\text { small }+ \text { lakeDIM }]} \\
& {[\text { smallDIM }+ \text { girlDIM] }} \\
& {[\text { daughter }>\text { daughterDIM }>} \\
& \text { daughterDIMDIM] }
\end{aligned}
$$

${ }^{2}$ The form hčerka is felt by some native speakers of Slovene to have been neutralized into an unmarked designation. 
These multiple diminutives and the ability of analytic and synthetic diminutive forms to be freely interchanged already gives us a clue as to the strong presence of diminutiveness in the language system of Slovene and testifies to the frequent use of diminutives in both spoken and written, and also in both formal and informal Slovene.

\subsection{Verbal Diminutives}

The formation of verbal diminutives in Slovene is by no means a rare phenomenon, although the prototypical diminutive in all languages is a denominal noun (i.e., a complex noun derived from another noun by suffixation). ${ }^{3}$ In Slovene linguistics, diminutive verbs have been treated by Toporišič $(1991,159)$ and Vidovič Muha $(1988$, 24). In order to express diminutiveness of or emotionality toward the verbal action, a neutral verbal base is furnished with an infix ${ }^{4}$; Toporišič lists seven of these $(-k-,-c ̌ k-$, $-c-,-i c-,-i n c-,-l j-,-i k-)$, and Vidovič Muha adds the infix -uck-.

$$
\begin{array}{ll}
\text { [nekoliko] voh [-a-ti] >-lj-, voh-, }-a-t i>\text { voh-lja-ti } & \text { [smellDIM] } \\
\text { [malo] stop[-a-ti] }>-i c-, \text { stop-, }-a-t i>\text { stop-ica-ti } & \text { [stepDIM] } \\
\text { [ljubko] smej[-a-ti] >-čk-, smej-, -a-ti }>\text { smej-čka-ti } & \text { [laughDIM] } \\
\text { [prijetno] drem [-a-ti] >-uck-, drem-, -a-ti }>\text { drem-ucka-ti } & \text { [dozeDIM] }
\end{array}
$$

As with nominal diminutives, multiple diminutiveness is possible in verbal diminutives, although it is less frequent than nominal multiple diminutiveness. In multiple verbal diminutives there is either double infixation or a prefix is added to the base along with a diminutive infix; the prefix used in the diminutive function always carries the adverbial value of 'small quantity', as in the following cases:

$$
\begin{array}{ll}
\text { stopati }>\text { stopicati }>\text { stopicljati } & {[\text { step }>\text { stepDIM }>\text { stepDIMDIM] }} \\
\text { vohati }>\text { vohljati }>\text { ovohljati /povohljati } & {[\text { smell }>\text { smellDIM }>\text { smellDIMDIM] }}
\end{array}
$$

Naturally, verbal diminutiveness can also be expressed analytically or periphrastically in Slovene. In this case the periphrase contains an adverbial component 'a little', 'a bit', or, alternatively, 'lovely', 'nicely', which express the quantitative or positive evaluation of the verbal action, as in the following examples:

${ }^{3}$ As a rule, the word class of the base is retained in the process of diminutive suffixation. When forming a diminutive, the semantic component [+small] is added to the meaning of the base and, optionally, also the component [+emotional attitude]. Because the word class in this word-formational process is generally retained, most grammarians have preferred to refer to the diminutive process as modification rather than derivation proper (see, for example, Erben 1983, 66, for German, and Vidovič Muha 1988, 24, and 1995, 158ff, for Slovene). Schneider $(2003,6)$, however, notices that in both English and German, some diminutive suffixes can "effect a word-class change" when added to adjectives (e.g. short $(\operatorname{adj})>$ shorty (noun); sweet $(\operatorname{adj})>$ sweetie $($ noun) $)$.

${ }^{4}$ The term used for this type of morpheme in Slovene linguistics is vpona. 

malo vohati
[smell + a little]
ljubko smejati (se)
[laugh + nicely]

Similarly as in the case of nominal diminutives, verbal diminutives too can have multiple diminutiveness, in which the analytic and synthetic types of expressing diminutiveness are combined.

\section{malce povohljati ${ }^{5}$ \\ nekoliko pojokcati}

$$
\begin{aligned}
& {[\text { smellDIMDIM }+ \text { a littleDIM] }} \\
& {[\text { cryDIMDIM }+ \text { a little }]}
\end{aligned}
$$

\section{Patterns for Expressing Diminutiveness in English \\ 2.1 Nominal Diminutives}

While diminutiveness in Slovene is mostly expressed by means of suffixes within a lexeme, the English language only occasionally expresses diminutiveness in this same, synthetic way. Expressing diminutiveness in English often demands going beyond the borders of a lexeme and, consequently, stretches over an entire syntactic structure or even sentence. Traditionally, linguists have considered English a language with hardly any diminutives (see, for example, Schneider 2003, 75, quoting Jespersen, Wierzbicka, Turner). Even more recent works on English word formation seem to deal perfunctorily with diminutiveness; thus, for example, Plag (2003, 13, 120-21) comments on diminutiveness only in terms of pet forms where clipping is combined with suffixation. Adams $(2001,55-58)$ covers diminutives in more detail, listing eight nominal suffixes with (partly) diminutive meaning. Further, Bauer (2002, 1677-78) lists five regular suffixes, two prefixes, and a few irregular or historical forms. Schneider (2003: 78), on the other hand, enumerates as many as eightysix different formatives that can be classified as diminutive suffixes of English, but, admittedly, many of these are only rarely used or are decidedly foreign in origin. Schneider (2003: $85 \mathrm{ff}$ ) analyzes the following fourteen suffixes as present-day diminutive English suffixes: - $a$, -een, -er, -ette, -ie/-y/-ey/-ee, -kin, -le, -let, -ling, -o, -peg, - poo(h), -pop, $-s$. However, it needs to be stressed that among these suffixes there are some that are extremely rare or dialectal. In fact, the only truly productive and universally used diminutive suffix in English seems to be the suffix -ie with its variants $-y /-e y /-e e$, which is often colloquial or informal. Like in Slovene, the suffix is attached to a nominal base to produce a diminutive form.

$$
\begin{array}{ll}
\text { [small] kitchen }>\text { kitchen-ette } & \text { [kitchenDIM] } \\
\text { [baby] boot }>\text { boot-ee } & \text { [bootDIM] }
\end{array}
$$

\footnotetext{
${ }^{5}$ Such expressions are found predominantly in literary texts.
} 
Occasionally, prefixation, clipping, compounding, or reduplication is used to produce synthetic diminutive nouns in English (see Schneider 2003, 8, 84; Bauer 2002, 1678).

$\begin{array}{ll}\text { microwave, minicab } & \text { (prefixation) } \\ \text { sec }(<\text { second) } & \text { (clipping) } \\ \text { baby lion, dwarf conifers } & \text { (compounding) } \\ \text { Annie-Pannie } & \text { (reduplication) }\end{array}$

As already mentioned, it is far more common to express diminutiveness by means of analytical formations in English; in these diminutive expressions we encounter nouns premodified by the adjectives small, little, and the more specific diminutive, tiny, wee, and so on.

\section{a little girl \\ small children \\ his diminutive kitchen}

Of these, the adjectives small and little are frequently used; however, it needs to be noted that while small used in its literal meaning appears in neutral contexts, little carries an additional emotional component (see Schneider 2003, 126; Klinar 1996, 199). Thus, for example, a small house is more appropriate in neutral or technical texts, while the syntagm a little house is more readily encountered in literary texts (see, for example, Klinar 1996, 199), but this seems to be a tendency rather than a hard and fast rule.

Multiple diminutives occur rarely in English. When used, the emotionality of the context is clearly visible.

Once upon a time in a tiny little cottage lived the three bears;

One was the papa bear, one was the mama bear, one was the wee bear [...]

(taken from: Goldilocks and the Three Bears)

\subsection{Verbal Diminutives}

Unlike Slovene and some other languages, ${ }^{6}$ English cannot form verbal diminutives through word formation. Verbal diminutiveness can only be expressed descriptively or periphrastically. In these cases, the pattern used is similar to the one found in

${ }^{6}$ Verbal diminutives can, for example, be found in German (denken $>$ denkeln) (see Schneider 2003, 5). Some of the verbal diminutives formed in this way have become lexicalized (lachen > lächeln). Similar pairs can be encountered in Slovene (smejati > smehljati [laugh > smile]; vohati $>$ vohljati [smell $>$ snoop]). Verbal diminutives also exist in Italian (see Dressler and Merlini Barbaresi 1994). 
Slovene analytical verbal diminutiveness (i.e., adverb with the semantic component [little] + verb) or the verb used is a lexicalized verb with a specialized meaning, where the adverb can sometimes be detected in the semantic base or the dictionary definition.

whimper

smile

cry a little

\section{The Semantic Categorization of Slovene and English Diminutives}

The basic, prototypical semantic meaning of a diminutive is denotative and refers to the (small) size of the referent (see Schneider 2003, 10). The feature [small] is added to the base, indicating that the referent is smaller than the average of the category that the referent belongs to. This applies to both Slovene and English diminutives.

$$
\begin{aligned}
& \text { kuhinja }+[\text { majhen }]>\text { kuhinjica } \\
& \text { kitchen }+[\text { small }]>\text { kitchenette }
\end{aligned}
$$

(kitchenDIM)

Quite often, however, the semantic feature [small] may not be restricted to size only, but may also be slightly extended to denote the age of the referent, adding the semantic feature [young] to the base.

$$
\begin{aligned}
& \text { raca }+[\text { mlad }]>\text { račka } \\
& \text { duck }+[\text { young }]>\text { duckling } \\
& \text { prašič }+[\text { mlad }]>\text { prašiček } \\
& \text { pig }+[\text { young }]>\text { piglet }
\end{aligned}
$$$$
\text { (pigDIM) }
$$

Additionally, most diminutives also seem to express some connotative value (see, for example, Schneider 2003, 1; Adams 2001, 13). In these cases, a semantic feature carrying some kind of relative evaluation is added to the base, expressing the speaker's emotional attitude toward the referent, which can be either positive or negative in connotation.

$$
\begin{aligned}
& \text { mama }+[\text { drag, ljub }]>\text { mamica } \\
& \text { mum }+[\text { dear, sweeet }]>\text { mummy } \\
& \text { predavanje }+[\text { ničvreden }]>\text { predavanjee } \\
& \text { lecture }+[\text { worthless }]>\text { lecturette }
\end{aligned}
$$$$
\text { (motherDIM) }
$$$$
\text { (lectureDIM) }
$$ 
It needs to be stressed that the connotative values of individual diminutives may vary considerably, depending on the situational contexts and linguistic factors. Another point to bear in mind is the frequent overlapping of the denotative and connotative elements within the same diminutive; it is often difficult, if not impossible, to draw a division line between denotation and connotation.

Another group of nominal diminutives deserves special attention as to its semantics. These nouns are diminutive in form only, but their semantic meaning has specialized so that they no longer express any diminutiveness. Quite often, they seem to have been formed on the basis of metaphoric association with the diminutive or its base form (see Snoj 2011).

metulj [butterfly] > metuljček [little butterfly] > metuljček [bow-tie] steklenica [bottle] > steklenička [little bottle] > steklenička [baby bottle] copat [slipper] > copatek [child's slipper] > copatek [ballet shoe] brada [beard] > bradica [little beard] > bradica [goatee]

In some other examples, the analogy has been completely lost or never existed at all, and these lexicalized diminutives are simply used as neutral forms filling lexical gaps; the bases they are supposedly derived from carry a different meaning altogether or are nonexistent.

marelica $(<$ ?marela) [apricot]

babica $(<$ ?baba) [midwife]

vrtec $(<$ ?vrt) [kindergarten, nursery school]

spominek $(<$ ?spomin) [souvenir]

These lexicalized diminutives are often found in technical language, thus acquiring the status of technical terms.
bobnič [eardrum] /anatomy/
rakec [small crab] /zoology/
matica [nut] lengineering/
lepi čeveljc [lady slipper orchid] /botany/

Such diminutiveness is practically unknown in English, as can already be inferred from the English translation equivalents in the preceding examples. Diminutiveness is only expressed in a few of the lexicalized English examples quoted above, be it through word-formation processes (e.g., the compound baby bottle and the suffixations goatee and statuette) or syntactically-analytically (e.g., small crab).

Among the lexicalized verbal diminutives in Slovene are the verbs smehljati (se) and vohljati (see footnote 6); as their semantic/translational equivalents English uses lexicalized verbs (smile and snoop) that are not diminutive in form. 


\title{
4 Comparison of Contexts with Diminutives in Slovene and English-An Analysis
}

This part of the article introduces an analysis of Slovene texts in which either nominal or verbal diminutives are used and compared to their translations into English. ${ }^{7}$ The selected texts aim to illustrate how the diminutive meaning of the Slovene original (whether denotative or connotative) often needs to be distributed along an entire syntactic structure in English if diminutiveness is to be expressed. While some contexts can indeed be translated directly with English diminutives, in most translations diminutiveness exceeds word and phrase boundaries of the Slovene originals. Some of the contexts below clearly illustrate how the constructions express either inherent diminutiveness by their form alone or adherent diminutiveness, which is encoded in the syntactic structure or the context. Again, we need to bear in mind that the diminutive values encoded in individual diminutive constructions may vary and are to be judged in relative terms, particularly in the case of connotative diminutiveness.

\begin{abstract}
Betnava je res bila "čudovit baročni dvorec", kot je 17. t.m. na TV rekel minister Školč, vendar kot pravijo domačini, le do konca 2. svetovne vojne. Zdaj je le še za silo obnovljen in vzdrževan gradič, in še to ne po zaslugi države, ampak predvsem po zaslugi Lipe iz Ajdovščine in nekaj tudi lokalne skupnosti. (Delo, 1.7.1999)

Betnava used to be a "wonderful baroque manor," as Minister Školč put it on the 17th of this month in a TV programme; however, according to the local people, that was only until the end of the Second World War. Now Betnava is nothing but an insignificant little castle, poorly restored and barely preserved, with no funds from the state, on top of everything, and kept up mostly by Lipa from Ajdovščina and partly by the local community. (transl. Černe)
\end{abstract}

The two nominal diminutives in this context, dvorec and gradič, illustrate the denotative and connotative meanings, respectively, while the referent remains the same. The semantically neutral diminutive (baročni) dvorec is thus translated as (baroque) manor (an even more frequently used English collocation would be baroque mansion), while the slightly pejorative gradic demands a different translation - the translator opted for the phrase insignificant little castle to convey the sense of negative connotation.

Resda domača zmaga niti za hipec ni bila ogrožena, a tako tekoče igre kot v lepem drugem delu le ni bilo. (Delo, 20.3.2007)

Although the victory of the home team was not jeopardized even for a second, the game was not as smooth as in the exciting second part. (transl. Černe)

${ }^{7}$ The Slovene texts have been taken from the corpus Nova beseda, while their translations into English have been quoted from Černe (2011) or translated by the author of the present article. 
The Slovene text uses the diminutive hipec [momentDIM], although the base form hip [moment] could be employed instead with practically no change in meaning. Although the translator decided to use a non-diminutive form a second in his English translation, the meaning of the entire Slovene context is correctly rendered into English, even though it lacks the diminutive form.

“Bi prišla naprej ti, s čopki ... lahko tudi z mamico. Boš bombonček?” je prvo gostjo spodbudila voditeljica. (Delo, 10.8.2005)

"You, with pigtails . . . yes, you can bring your mommy, too. How about some candy, sweetheart?" the hostess encouraged her first guest. (transl. Černe)

This Slovene context includes three diminutives and is taken from child-oriented speech in which diminutives are commonly used in most languages. The first diminutive noun, čopki, suggests that the little girl addressed was a small child wearing her hair plaited into pigtails. In the English translation, pigtails has been used but nothing else diminutive to suggest the child's small size. The diminutive mamica has been translated by using the corresponding English diminutive mommy, which is one of the rare examples where the two languages correspond in the use of diminutive equivalents. The third diminutive, bomboncek [candyDIM], has again been translated using a neutral non-diminutive noun in English (candy). However, the translator here added the endearment noun sweetheart, inserting into the translation some further positive connotative value with which to enhance the English context, compensating for its lack of diminutiveness in pigtails and candy.

“Oj, pa si že vstala? Zgodaj je še in ti bi še lahko spančkala v posteljici. Pa zakaj si tako zgodaj vstala?" (Vandot: Kekec na volčji sledi)

"Up already? It's still early, angel, you could've slept in your little bed a little longer. Why did you get up so early?" (transl. Cerne)

Another child-oriented text, this one has been taken from literature. The synthetic Slovene diminutive posteljica [bedDIM] becomes the analytic noun phrase little bed in English. Interestingly, the translator here added the noun angel, by which the little girl is addressed in the translation; by doing so, he probably tried to compensate for the lack of diminutiveness that is expressed in the Slovene diminutive verb spančkati and that cannot possibly be expressed by using a single verb in English.

Kdo misli, je nabijal Adam z vrčem po mizi, kdo misli, da bo ta smrkavi cesarček s svojim podkupljivim uradništvom, s samovoljnimi stanovi, s pogoltno duhovščino, s svojo dobro voljo in s svojim slabištvom napravil red v tej prekleti zmedeni deželi? (Jančar: Galjot) Tell me who could think, Adam was slamming his mug against the table, who could possibly think that this little brat of an emperor is capable of setting things straight in this goddamn messed-up country with his corrupted officials, disobedient classes, greedy clergy, with his positive spirit and his spinelessness? (transl. Černe) 
In this context, again taken from a literary text, the Slovene diminutive form clearly expresses pejorative meaning; smrkavi cesarček could literally be interpreted as snotty little emperor. The translator opted for this little brat of an emperor, which fully conveys the meaning intended by the author, with the Slovene diminutive in this case expressed using an analytical diminutive phrase in English.

To pa pomeni, da je naše morebitno članstvo odloženo za nekaj let ali kar ad calendas graecas. Po drugi strani pa bomo v teh nekaj letih najbrž vendarle sprejeti v EU in tako bo odpadel tisti argumentek, ki pravi, da je za našo varnost dobro, da smo vsaj v Natu, dokler ne bomo v Uniji. (Delo, 4.8.2001)

This, however, means that our potential membership will be postponed for a few years, or even "ad calendas graecas," so to speak. On the other hand, we will probably become a full member of the EU in the next few years after all, which will discredit that piffling argument supporting the belief that it would be safer for us to be at least a NATO member until we finally obtain EU membership. (transl. Černe)

This pejorative journalistic text clearly shows that Slovene can easily form diminutives from practically any nominal base (argument $>$ argumentek). Although English has some pejorative suffixes that can also be used diminutively (e.g., -ette, -so), the language obviously prefers to use an analytical equivalent to express the same meaning: the noun argument is premodified by the slightly informal adjective piffling, which adds a pejorative tone to the English translation. Still pejorative, but slightly less informal, would be the phrases trifling argument or trivial argument.

Našemu sodelavcu Mitji Šumaku je na eni največjih kasaških dirk na svetu, Elitloppu na Švedskem, uspelo fotografirati nagca, ki je na progo hušknil med 4. in 5. dirko. Vsega hudega vajeni varnostniki ga sploh niso zaustavljali, očividci pa so mnenja, da je bil $\boldsymbol{d e}$ belušček tudi zmerno okajen. (Delo, 7.6.1999)

During Elitlopp, one of the biggest horse racing events in the world that takes place in Sweden, our correspondent Mitja Šumak managed to take a shot of a man who jumped onto the tracks stark naked between the 4 th and the 5 th race. The security guards, who are probably used to all sorts of eccentricities, did not even make an attempt to stop him, and the eyewitnesses claim that the chubby prankster appeared to be rather "merry" too. (transl. Černe)

The diminutive debelušček [fat manDIM] used in the above context is again connotative in meaning and adds a decidedly jocular tone to the text. The translator decided to convey this same meaning in English by using the phrase the chubby prankster; thus, the component [fat] is expressed in the adjective chubby, and the humorous, jocular quality of the fat man's action in the noun prankster. Using the English noun diminutives fatty and fatso here would be clearly wrong as they convey pejorative shades of meaning that the source-language item lacks. ${ }^{8}$

${ }^{8}$ Schneider $(2003,111)$, however, claims that fatty can be positive in connotation, although Sinclair $(2001,566)$ clearly states that the noun is used to express disapproval. 
Za prihodnje leto je najprej predvideno čiščenje usedlin iz kanala za dovod morske vode, očistiti bo treba preliv med malim jezercem in večjo vodno laguno, z območja zatoka pa se bodo morali umakniti tudi mali vrtičkarji. (Delo, 15.12.1998)

The schedule for next year includes clearing the sediments for the seawater supply channel, clearing the passageway between the little lake and the bigger water lagoon; also, garden owners will be asked to leave the area around the inlet. (transl. Černe)

This context contains two Slovene diminutives, malo jezerce and mali vrtičkarji; both are double diminutives in which analytical and synthetic diminutives are combined to enhance the expressive force of diminutiveness. This kind of gradation is nearly impossible to render in English, malo jezerce [little lakeDIM] is therefore translated as little lake, while mali vrtičkarji [owners of little gardensDIM] can only be rendered as garden owners and its diminutiveness is lost in translation.

Na glavi ima majhno, visoko čepico iz črnih čipk, ki so tako trdo naškrobljene, da je videti, kakor bi bile izrezljane iz starega lesa in ne stkane iz rahlih nitk. Njen drobčkani obraz je ves naguban in zarjavel od žgočega južnega sonca. (Kosmač: Težka nedelja)

She is wearing a small, tall hat with black lace starched so heavily that it seems as though it had been carved out of an old piece of wood rather than knitted with delicate yarn. Her tiny face has wrinkled and burnt under the southern sun. (transl. Černe)

This literary text contains two analytical diminutives that are translated analytically into English. The neutral phrase majhna čepica [small hatDIM] has been rendered as a small hat, and the more expressive phrase drobčkani obraz [tinyDIM face] has been rendered as her tiny face. The next context too shows how an analytical diminutive in Slovene [smallDIM brat] can be translated into English directly by using a corresponding analytical diminutive:

In Bjork? Fino je bilo videti, kakšna majčkena bledolična smrklja je. In kakšen glas! (Delo, 23.6.2001)

And what about Bjork? It was nice to see what a teeny pale brat she is. And what a voice! (transl. Černe)

Such direct, literal rendition of Slovene diminutives into English seems to be possible mainly in the case of Slovene analytical diminutive formations (whether denotative or connotative) and synthetic formations denoting primarily family relationships where English has formed a corresponding suffixed equivalent.

The following three texts contain Slovene double verbal diminutives (pocmoklja$t i$, priskakljati, and the connotative pojokcati) that are translated into English using the equivalent lexicalized verbs smack [(za/po)cmokati], hop [skakati, (po)skočiti], and whimper [(za)hlipati, (za)stokati]. All three English verbs can denote either momentary or durative actions, and the diminutive semantic nuances expressed by the Slovene originals are mainly lost in the English translations. 
Hipoma pocmoklja z jezikom in ustnicami in z okroglo, polno roko udari na lahko po napetih hlačah. (Pugelj: Zakonci)

He shortly smacks his lips and tongue, and then gently slaps his bulging trousers with his round, fleshy hand. (transl. Černe)

V daljavi prečka savano trop slonov, žirafe pa se naprezajo za zelenjem visoko na drevju. Poleg njih se pasejo antilope in gazele, mednje pa vsake toliko časa priskaklja kakšen pavijan. (Delo, 5.1.2005)

In the distance a herd of elephants cross the savannah, and the giraffes are struggling to get to the leaves up in the treetops. Antelopes and gazelles are grazing next to them, and every now and again a baboon hops into their circle. (transl. Černe)

Vidim užaljen obraz. "Kaj bom jedel?” pojokca. "Briga me!” (Votolen: Pravica do sebe)

I see a displeased face. "What am I going to eat?" he whimpers. "Like I care!" (transl. Černe)

The verb svetlikati se as used in the following text could be classified as a denotative diminutive; in fact, English comes very close to this same meaning with its verb glimmer, which is defined as 'producing or reflecting a faint, gentle, often unsteady light' (see Sinclair 2001, 665). In the example below, however, the translator preferred to use the nominal phrase the first glimmer of light, which collocates ideally with the following verb.

Bilo je mrzlo. Skozi drevje se je začelo svetlikati. (Hace: Komisarjevi zapiski)

It was cold. The first glimmer of light was penetrating through the trees. (transl. Černe)

The next pair of texts illustrates another possible translation strategy: the connotative verbal diminutive igračkati se [playDIM] is translated into English by using the phrasal verb play around; the diminutive meaning is again lost in translation.

Približno takrat sta se Boris Benko in Primož Hladnik, ljubljanska elektropoparja Silence, ki svoj glasbeni okus dolgujeta 80. letom, začela igračkati s sintesajzerji. (Delo, 11.12.1999)

It was more or less during that period that Boris Benko and Primož Hladnik, the electro pop band from Ljubljana named Silence, strongly inspired by the 80 s, began to play around with synthesizers. (transl. Černe)

The following literary texts show how omnipresent diminutiveness is in Slovene and how extensively authors can use it. In the first text, the nominal diminutive usteca [mouthDIM] is rendered into English analytically as little mouth, while the verbal diminutive objemčkati [hugDIM] is transferred descriptively by using hug with lovely little arms. 
Ko se nama posreči spraviti prvi požirek mleka v tvoja usteca, me boš prijazno gledal in objemčkal kakor pravo mater, in jaz te poljubim na okroglo rdeče lice prav tako kakor mati! (Mencinger: Moja hoja na Triglav)

When we manage to get the first sip of milk into your little mouth, you'll give me a loving look and hug me with your lovely little arms like a real mother, and I'll kiss you on your red round cheek just like a mother would do. (transl. Černe)

The next text shows that in the translation of nominal diminutives, English can keep up with Slovene to some degree by using its own phrasal equivalents: čeveljčki [shoesDIM] becomes little shoes, and kljunček [beakDIM] turns into sweet little mouth. Interestingly enough, the suffixation ptičica [birdDIMDIM] finds its English equivalent in the double diminutive lovey dovey, in which suffixation is combined with reduplication. Obviously, the translation had thus become so packed with emotionality that the translator chose to ignore the diminutiveness of the Slovene verb papcati [eatDIM] and left it out altogether.

Res, da je človek nekoliko rejen, nekoliko len in zelo neumen, toda za ženina in za moža je kakor ustvarjen. Klečal bo pred teboj, sezuval ti čeveljčke ter ti še devet let po poroki donašal bonbonov: "Ná, ptičica, odpri kljunček in papcaj!" (Cankar: Milan in Milena) True, the man is a bit plump, a bit lazy, and very stupid, but he was born to be a groom and a husband. He will kneel in front of you, he will take off your little shoes, and even nine years after the wedding he will still buy you sweets: "Here, lovey dovey, open your sweet little mouth!" (transl. Černe)

When Slovene lexicalized diminutives are translated into English, the corresponding English terms rarely also have diminutive suffixes, as in the pairs bradica-goatee, kipec-statuette. Rather, the equivalents in English are in most cases lexemes with no diminutiveness expressed in them, as, for example, in:

Pravijo, da je letošnja bera odlična. Ne bo pa marelic in breskev. (Delo, 16.6.2001) This year's harvest is said to be excellent. However, there won't be any apricots and peaches. (transl. Sicherl)

Princ Charles bo sinovoma Williamu (17) in Harryju (15) z zadnjega obiska v Franciji prinesel zanimiva spominka. (Delo, 6.6.2000)

Prince Charles will bring two interesting souvenirs to his sons William (17) and Harry (15) from his last visit to France. (transl. Sicherl)

Tonio Gomez se smehlja, ob njem sedi ženska, videl jo je na eni od Gumbovih fotografij z izplazenim jezikom. (Jančar: Posmehljivo poželenje)

Tonio Gomez is smiling, next to him sits a woman whom he has seen in one of Gumbo's photos with a stretched-out tongue. (transl. Sicherl)

However, the translation of such diminutive forms into English proves to be the least demanding, precisely because of the lexicalized status of these lexemes; their meanings are consequently well covered by dictionaries. 


\section{Concluding Remarks}

The Slovene language seems to form and use diminutives quite naturally and with great ease. Consequently, diminutives can be found in all language levels and styles: from spoken to written varieties, from colloquial and informal registers to literature. In this respect, English seems more reserved and less productive, so it is not surprising that diminutive structures in English are primarily found in present-day informal speech, as in conversation between family members, friends, acquaintances, and neighbors (see Schneider 2003, 137).

While Slovene uses its language-systemic/word-formational capacities to form synthetic diminutives, combines these with analytic formations, and also makes use of gradation of diminutives, English seems morphologically less productive in this respect. As to word-formation processes, diminutive suffixation in English is productive only in the case of the suffix -ie and its variants in nouns. The need to express diminutiveness in English must therefore be satisfied by using syntactic or analytic structures, and, when compared to Slovene, it seems to lag only slightly behind in this aspect. However, English seems to be less able to cope with the wealth of verbal diminutives in Slovene. Here the extreme word-formational potential of Slovene is clearly shown in that English often cannot follow the subtle semantic nuances expressed by diminutives, and must consequently describe, paraphrase, or even omit certain elements in translation.

Within monolingual Slovene diminutive research, it is therefore possible to remain limited to the lexemic-morphological level and analyze Slovene diminutives exclusively in terms of word formation. As soon as the research includes English, the analysis must expand to syntax and context, as diminutiveness in English can often be expressed only beyond the borders of single words.

\section{References}

Adams, Valerie. 2001. Complex Words in English. Harlow, Essex: Pearson Education.

Bajec, Anton. 1950. Besedotvorje slovenskega jezika I: Izpeljava samostalnikov. Ljubljana: SAZU.

Bauer, Laurie, and Rodney Huddleston. 2002. Lexical word-formation. The Cambridge Grammar of the English Language, edited by Rodney Huddleston and Geoffrey K. Pullum, 16211721. Cambridge: Cambridge University Press.

Černe, Simon. 2010. Translation of Slovene diminutives into English (bachelor of arts thesis). Ljubljana: Filozofska fakulteta.

Dressler, Wolfgang, and Lavinia Merlini Barbaresi. 1994. Morphopragmatics. Diminutives and Intensifiers in Italian, German, and Other Languages. Berlin: Mouton de Gruyter.

Gajda, Stanisław, ed. 1995. Języki stowiańskie 1945-1995: Gramatyka-leksyka-odmiany. Opole: Uniwersytet opolski, Instytut filologii polskiej.

Huddleston, Rodney, and Geoffrey K. Pullum. 2002. The Cambridge Grammar of the English Language. Cambridge: Cambridge University Press. 
Klinar, Stanko. 1996. Prevajanje slovenskih manjšalnic. Prispevki $k$ tehniki prevajanja iz slovenščine v angleščino, edited by Stanko Klinar, 194-212. Radovljica: Didakta.

Klinar, Stanko, ed. 1996. Prispevki k tehniki prevajanja iz slovenščine v angleščino. Radovljica: Didakta.

Nova beseda: Besedilni korpus na Inštitutu za slovenski jezik Frana Ramovša ZRC SAZU. $<\mathrm{http}$ ///bos.zrc-sazu.si/s_beseda.html.>

Plag, Ingo. 2003. Word-Formation in English. Cambridge: Cambridge University Press.

Schneider, Klaus P. 2003. Diminutives in English. Tübingen: Max Niemeyer.

Sinclair, John, ed. 2001. Collins DOBUILD English Dictionary for Advanced Learners. Glasgow: HarperCollins.

Snoj, Jerica. 2011. Metaforična pomenotvornost z vidika sintagmatike. Jezikoslovni zapiski 17(2): 93-105.

Stramljič Breznik, Irena. 2007. Besedotvorna kategorija samostalniških manjšalnic v Pleteršnikovem slovarju in v SSKJ. Zora 57. Maribor: Filozofska fakulteta UM.

Stramljič Breznik, Irena. 2010. Tvorjenke slovenskega jezika med slovarjem in besedilom. Zora 71. Maribor: Filozofska fakulteta UM.

Toporišič, Jože. 1991. Slovenska slovnica. Maribor: Založba Obzorja.

Vidovič Muha, Ada. 1988. Slovensko skladenjsko besedotvorje ob primerih zloženk. Ljubljana: ZIFF, Partizanska knjiga.

Vidovič Muha, Ada. 1995. Dva tipološka zgleda normativne vrednosti slovenske besedotvorne morfematike. Języki stowiańskie 1945-1995: Gramatyka-leksyka-odmiany, edited by Stanisław Gajda, 153-64. Opole: Uniwersytet opolski, Instytut filologii polskiej.

Prispelo novembra 2011, sprejeto marca 2012

Received November 2011, accepted March 2012

\section{Slovenski manjšalni samostalniki in glagoli v primerjavi $\mathrm{z}$ angleškimi ustreznicami}

Pričujoča razprava obravnava različne načine za izražanje manjšalnosti v slovenščini in angleščini; težišče članka je na besedotvornih in skladenjskih značilnostih manjšalnih struktur v obeh jezikih. Najprej predstavi vzorce za izražanje manjšalnosti v slovenščini; deli jih na besedotvorne oziroma sintetične, kjer prevladuje izpeljava (bik $>$ bikec), redkeje se pojavljajo krnitev (Ladislav $>$ Lado $>$ Ladko/Ladi), zlaganje (minikrilo, mikrofilm) in podvojitev (Žogica Marogica), ter skladenjske oziroma analitične (majhna hiša). Pri tem opaža, da so ti manjšalni vzorci večinoma zamenljivi (majhen $k o s=k o s ̌ c ̌ e k$ ) ali se celo dopolnjujejo pri t.i. večstopenjski manjšalnosti (majhno jezerce). Stanje je podobno pri glagolskih manjšalnicah, kjer sintetične izpeljujemo z infiksacijo (vohati > vohljati), pri večstopenjski manjšalnosti pa vpono podvojimo (stopati $>$ stopicati $>$ stopicljati) ali ji dodamo predpono (vohati $>$ vohljati $>$ ovohljati); analitično tvorjene glagolske manjšalnice pa vsebujejo prislove $\mathrm{s}$ 
kolikostnim ali pozitivnim vrednotenjem glagolskega dejanja (malo vohati), ki so znova lahko stopnjevane (malce povohljati). V nadaljevanju se razprava osredotoči na vzorce za izražanje manjšalnosti v angleščini; tam je pri samostalnikih sintetičnih manjšalnic tvorjenih z izpeljavo nekoliko manj (kitchen > kitchenette), najdemo pa tudi manjšalne zloženke (baby lion), sestavljenke (minicab), krnitve (sec) in podvojitve (Annie-Pannie); zaradi tipologije jezika prevladuje analitična oziroma skladenjska manjšalnost (small children), večstopenjska manjšalnost pa je redka. Angleških glagolskih manjšalnic tvorjenih sintetično ni; manjšalnost je v tem primeru treba izraziti analitično (cry a little), ali pa z leksikaliziranim glagolom s specializiranim pomenom (whimper). V nadaljevanju so slovenske in angleške manjšalnice kategorizirane pomensko; tu pri obeh jezikih razlikujemo denotativni in konotativni pomen, ki se pogosto prekrivata. Poleg tega pa slovenščina dokaj pogosto tvori tudi manjšalne oblike, ki se leksikalizirajo in uporabljajo nevtralno (marelica, spominek), nekatere imajo status strokovnih terminov (bobnič). V angleščini je takšnih leksikaliziranih manjšalnic zelo malo (goatee).

Sledi analiza sobesedil, kjer se manjšalnice pojavljajo v slovenskih besedilih, z njihovimi prevodi v angleščino; tu se potrdi domneva, da slovensko enobesedno samostalniško manjšalnico pogosto $\mathrm{v}$ angleščino prenesemo analitično, glagolsko manjšalnico pa lahko izrazimo le, če manjšalnost prerazporedimo po vsej skladenjski stukturi.

\section{Diminutive Nouns and Verbs in Slovene Compared to Their English Equivalents}

The present article deals with various ways in which diminutiveness can be expressed in Slovene and English; the focus is on word-formational and syntactic properties of diminutive structures in both languages. First, patterns for expressing diminutiveness in Slovene are presented and classified into word-formational or synthetic patterns, with suffixation (bik $>$ bikec) dominating over clipping (Ladislav $>$ Lado $>$ Ladko/ Ladi), compounding (minikrilo, mikrofilm), and reduplication (Žogica Marogica), and also over syntactic or analytic patterns (majhna hiša). These diminutive patterns are mostly interchangeable (majhen kos $=k o s ̌ c ̌ e k$ ) or, in the case of multiple diminutives, even complement one another (majhno jezerce). The situation is similar in verbal diminutives, where synthetic forms are derived by infixation (vohati $>$ vohljati), while in double diminutiveness another infix is added to the existing one (stopati $>$ stopicati $>$ stopicljati) or a prefix is added to the already diminutivized form (vohati $>$ vohljati $>$ ovohljati). Verbal diminutives formed analytically, however, contain adverbs expressing a quantitative or positive evaluation of the verbal action (malo vohati), which can again undergo gradation (malce povohljati). The article continues with a presentation of patterns for expressing diminutiveness in English. In English nouns, synthetic diminutives formed by suffixation are less common than in Slovene (kitchen > kitchenette), while diminutives are more frequently formed using 
compounds (baby lion), prefixations (minicab), clippings (sec), and reduplications (Annie-Pannie). Due to language typology, analytical or syntactic diminutiveness prevails in English (small children), and multiple diminutiveness is rare. There are no verbal synthetic diminutives in English, meaning diminutiveness in verbs must be expressed analytically (cry a little) or by using a lexicalized verb with a specialized meaning (whimper). In the following part, Slovene and English diminutives are categorized semantically. In both languages, diminutives can have denotative or connotative meanings, which often overlap. Apart from that, Slovene frequently forms diminutive forms that are lexicalized and used neutrally (marelica, spominek); some of these have acquired the status of technical terms (bobnic). In English, such lexicalized diminutives are very rare (goatee). The semantic part is followed by an analysis of Slovene contexts in which diminutives appear and compares their translations into English. This comparison confirms the assumption that Slovene single-word nominal diminutives are often translated into English analytically, while Slovene verbal diminutives can be expressed in English only by distributing the diminutive meaning along an entire syntactic structure. 